\title{
Paths towards Autonomy in Indigenous Women's Movements: Mexico, Peru, Bolivia
}

\author{
STÉPHANIE ROUSSEAU and ANAHI MORALES HUDON*
}

Abstract. Based on comparative research this article analyses indigenous women's organising trajectories and the creation of spaces where they position themselves as autonomous political actors. Drawing on social movement theory and intersectionality, we present a typology of the organisational forms adopted by indigenous women in Peru, Bolivia and Mexico over the last two decades. One of the key findings of our comparative study is that indigenous women have become social movement actors through different organisational forms that in part determine the degree of autonomy they can exercise as political subjects.

Keywords: indigenous women, Mexico, Peru, Bolivia, indigenous movements

'I think that it is time to talk about women's rights, like this, openly, because here in our organisation they have used the term gender in vain; at the previous executive council of our organisation, a man was appointed Secretary of Gender! And he didn't do anything for us women. So we said no, we no longer accept it.' ' These words from Justa Cabrera, former President of the Confederación Nacional de Mujeres Indígenas de Bolivia (CNAMIB), reflect the situation of many indigenous women activists. The CNAMIB was created in 2008 by hundreds of women from organisations affiliated with the Confederación de Pueblos Indígenas de Bolivia (CIDOB), the main indigenous organisation of the Bolivian lowlands. It became a wellrecognised political actor that managed to maintain its affiliation with the

Stéphanie Rousseau is a professor in the Department of Social Sciences at the Pontificia Universidad Católica del Perú. Email: srousseau@pucp.pe. Anahi Morales Hudon is a postdoctoral fellow at the Chaire Nycole Turmel sur les espaces publics et les innovations politiques, Université du Québec à Montréal. Email: morales.anahi@gmail.com.

* Special thanks to the indigenous women who agreed to participate in the interviews. We also wish to thank Patricia Richards and José Antonio Lucero for their comments on previous versions of this article. Finally, we also thank the anonymous referees for their insightful comments and the Social Sciences and Humanities Research Council (Canada) for funding this research.

${ }^{\text {I }}$ Interview with Justa Cabrera, former President of the Confederación Nacional de Mujeres Indígenas de Bolivia (CNAMIB), i 8 March 20 I I, Bolivia. 


\section{Stéphanie Rousseau and Anabi Morales Hudon}

CIDOB. Like Justa, indigenous women's organising processes in different countries, while taking different paths towards autonomy, are an intrinsic part of indigenous movements. However, within the literature on indigenous movements in Latin America, there is so far very little discussion of indigenous women's organising from a comparative point of view. Is there a relationship between the strength of an indigenous movement and the capacity of indigenous women to occupy significant spaces in its organisations? What are the factors explaining different configurations of indigenous women's participation in indigenous movements? Do indigenous women's contributions to indigenous movement dynamics vary from one case to another, and if so, why?

These questions are important in order to gain a more nuanced understanding of what these movements are made of and what kinds of social relations are reproduced within them. Indigenous women have been active participants in indigenous movements from their beginnings. However, the literature on indigenous movements in different countries reveals the difficulties women face in being recognised as legitimate political actors in the eyes of the state, civil society in general, women's movements, and in some cases, even within indigenous organisations. ${ }^{2}$ The questions guiding this article are therefore also useful for thinking about social movements as actors in a continual process of formation and transformation that are subject to internal contestation, and themselves the locus of various forms of discrimination and injustice. ${ }^{3}$ Moreover, as the feminist literature on social movements and politics in general has shown, too often gender-blind forms of studying political actors end up producing the idea that women do not have political agency or that their agency can be apprehended the same way as men's. ${ }^{4}$

This article presents the main results of a comparative research project on three cases of interest for the analysis of indigenous politics in Latin America: Mexico, Peru and Bolivia. As will be explained below, these cases present contrasting trajectories and outcomes of indigenous movements in national politics, which allows us to relate differing contexts to indigenous women's capacity to mobilise as collective actors. Indigenous women have mobilised within indigenous movements traditionally dominated by male

${ }^{2}$ Edna Acosta-Belén and Christine E. Bose, Researching Women in Latin America and the Caribbean (Boulder, CO: Westview Press, 1993); Sarah A. Radcliffe, 'Indigenous Women, Rights and the Nation-State in the Andes', in Nikki Craske and Maxine Molyneux (eds.), Gender and the Politics of Rights and Democracy in Latin America (New York: Palgrave, 2002), pp. 149-72; Patricia Richards, Pobladoras, Indigenas, and the State: Conflicts over Women's Rights in Chile (New Brunswick, NJ: Rutgers University Press, 2004); Shannon Speed, Rosalva Aída Hernández Castillo and Lynn Stephen, Dissident Women: Gender and Cultural Politics in Chiapas (Austin, TX: University of Texas Press, 2006).

${ }^{3}$ Benita Roth, Separate Roads to Feminism: Black, Chicana, and White Feminist Movements in America's Second Wave (Cambridge and New York: Cambridge University Press, 2004).

4 Yulia Zemlinskaya, 'Social Movements Through the Gender Lens', Sociology Compass, 4: 8 (2010), pp. 628-41. 
leaders and where no critical attention was given to gender relations. Our central argument is that in order to act autonomously as a collective representing a social group (indigenous women), they have built spaces of their own that both maintain their affiliation with indigenous organisations while gaining the right to speak as political subjects. One of the key comparative findings of our study is that indigenous women became social movement actors through a variety of organisational forms that in part determine the degree of autonomy they can exercise as political subjects. Yet the question of autonomy is complex in a context where indigenous women are nonetheless a part of indigenous movements and therefore need to remain legitimate actors within them.

The article is structured as follows: first we synthesise how the literature on women's movements and indigenous movements in Latin America has addressed indigenous women as political actors. We then present our own theoretical framework, combining intersectionality with analytical concepts from the social movement literature. Our perspective seeks to understand the contexts, patterns and forms adopted by indigenous women's mobilisation through attention to national political processes as well as intra-movement power relations. The last part presents the results of our comparison without pretending to generalise for all the cases found in the region.

\section{Indigenous Women in the Study of Women's and Indigenous Movements}

The literature on women's movements in Latin America is old, diverse and abundant. Women's role in the transitions to democracy, women's participation in guerrilla wars, women in electoral politics, grassroots survival-based women's organisations, or the variety of feminisms active in the region, have each received and continue to receive important theoretical and empirical attention, if only rarely through a systematic comparative framework. ${ }^{5}$ In these

$s$ Due to the abundance of the literature, only a select number of references are cited here. Jane S. Jaquette, The Women's Movement in Latin America: Feminism and the Transition to Democracy (Boston, MA: Westview Press, 1989); Sonia E. Alvarez, Engendering Democracy in Brazil: Women's Movements in Transition Politics (Princeton, NJ: Princeton University Press, 1990); Karen Kampwirth, Women and Guerrilla Movements: Nicaragua, El Salvador, Chiapas, Cuba (University Park, PA: Penn State Press, 2002); Linda L Reif, 'Women in Latin American Guerrilla Movements: A Comparative Perspective', Comparative Politics, I 8: 2 (1986), pp. 147-69; Susan Franceschet, Mona Lena Krook and Jennifer M. Piscopo, The Impact of Gender Quotas (New York: Oxford University Press, 20I 2); Mala Htun and Mark P. Jones, 'Engendering the Right to Participate in Decisionmaking: Electoral Quotas and Women's Leadership in Latin America', in Nikki Crase and Maxine Molyneux (eds.), Gender and the Politics of Rights and Democracy in Latin America (New York: Palgrave, 2002), pp. 32-56; Stéphanie Rousseau, Women's Citizenship in Peru: The Paradoxes of Neopopulism in Latin America (New York: Palgrave, 2009); Lynn Stephen, Women and Social Movements in Latin America: Power from Below (Austin, TX: University of Texas Press, 1997); Jane S. Jaquette, Feminist Agendas and Democracy in Latin America (Durham, NC: Duke University Press, 2009); Virginia 
works, for the most part, the ethnic identity of the women that mobilise is not an object of study and therefore indigenous women do not appear to be political actors.

Existing research on indigenous women as political actors has covered different national or sub-national cases within a particular country, but the majority of the works published are neither comparative, nor inserted in the tradition of the political process approach to social movements. Most of the existing literature focuses on the formation of collective identities articulating gender and ethnicity, and on the difficulties indigenous women face vis-à-vis both non-indigenous women's organisations and indigenous movements. ${ }^{6}$ Radcliffe et al. have studied the globalisation of ethno-development discourse and practices to show how indigenous women are marginalised and excluded from both state- and civil society-led initiatives. 7 They also argue, together with other authors, that indigenous organisations or their NGO allies often produce their indigenous 'authenticity' in part by arguing that gender relations in indigenous communities are distinct from those in the dominant society or by criticising liberal feminism as an extension of Western colonialism. ${ }^{8}$ Indigenous women are thus described as emblematic of indigenous culture in the discourse of indigenous movement leaders.

Vargas, Feminismos en América Latina: su aporte a la politica y a la democracia (Lima: Programa Democracia y Transformación Global, 2008).

${ }^{6}$ Rosalva Aída Hernández Castillo, 'The Emergence of Indigenous Feminism in Latin America', Signs, 35: 3 (2010), pp. 539-45; R. Aída Hernández Castillo, 'Entre el etnocentrismo feminista y el esencialismo étnico. Las mujeres indígenas y sus demandas de género', Debate Feminista, 24 (200I), pp. 206-29; Rosalva Aída Hernández (ed.), Etnografias e historias de resistencia. Mujeres indigenas, procesos organizativos y nuevas identidades politicas (México: CIESAS/PUEG-UNAM, 2008); Andrea Pequeño (ed.), Participación y politicas de mujeres indigenas en contextos latinoamericanos recientes (Quito: FLACSO, 2009); Manuela Picq, 'Gender Within Ethnicity: Human Rights and Identity Politics in Ecuador', in Guillermo O'Donnell, Joseph Tulchin and Augusto Varas (eds.), New Voices in the Study of Democracy in Latin America (Washington, DC: Woodrow Wilson International Center for Scholars, 2008); Mercedes Prieto, Clarinda Cuminao, Alejandra Flores, Gina Maldonado and Andrea Pequeño, 'Las mujeres indígenas y la búsqueda del respeto', in Mercedes Prieto (ed.), Mujeres ecuatorianas. Entre las crisis y las oportunidades (Quito: FLACSO and CONAMU, 2005), pp. I47-88; Radcliffe, 'Indigenous Women, Rights and the Nation-State in the Andes'; Richards, Pobladoras, Indigenas, and the State; Shannon Speed, Rights in Rebellion: Indigenous Struggle and Human Rights in Chiapas (Stanford, CA: Stanford University Press, 2008); Speed, Hernández Castillo and Stephen, Dissident Women; Lynn Stephen, 'Gender, Citizenship, and the Politics of Identity', Latin American Perspectives, 28: 6 (2001), pp. 54-69.

7 Sarah A. Radcliffe, Nina Laurie and Robert Andolina, 'The Transnationalization of Gender and Reimagining Andean Indigenous Development', Signs, 29: 2 (2004), pp. 387-416.

${ }^{8}$ Maruja Barrig, El mundo al revés: imágenes de la mujer indigena (Buenos Aires: CLACSOASDI, 200I); Hernández Castillo, 'Entre el etnocentrismo feminista y el esencialismo étnico'; Kay B. Warren and Jean E. Jackson, Indigenous Movements, Self-Representation, and the State in Latin America (Austin, TX: University of Texas Press, 2002). 
Burman reveals the different and clashing views of Aymara indigenous women activists who claim that colonialism is the source of their ills, and mestiza feminist activists who see an instrumentalisation of indigenous women in the official decolonisation discourse. ${ }^{9}$ Canessa has also very aptly shown the racialised and sexualised gender hierarchy in Bolivia's new indigenous politics under the rule of Evo Morales, demonstrating the contradictions of emancipatory discourses that reproduce indigenous women's oppression while promoting their political participation. ${ }^{\circ}$

Literature on indigenous movements that proposes explanatory frameworks to understand their political mobilisation has generally ignored gender as a variable. Yashar emphasises the dual transformation of Latin American societies towards neoliberal citizenship regimes and democratic politics that created both political associational space as well as new threats to the survival of indigenous communities. ${ }^{11}$ Lucero studies the competing forces that attempt to represent indigeneity in social movements through different repertoires and with more or less success depending on path dependent trajectories of collective action. In his insightful study, the question of how the indigenous political subject that is being represented is constructed is not discussed through a gendered frame. ${ }^{12}$

The predominant conceptualisation of political associational space considers social movements' political opportunities in relation to state repression or political rights, or else to the virtual absence of the state. This way of thinking about political opportunities does not reflect upon the particular contextual and institutional conditions for indigenous women's mobilisation. In the literature on women's mobilisation in the anti-authoritarian regimes of the I970s in Latin America, for example, one of the findings highlights the lesser repression exercised against women's organisations in comparison to male-dominated organisations, because women were framed as non-political actors and unthreatening maternal figures. ${ }^{13}$ In general, the literature argues for considering patterns of gender segregation or stratification in the broader society as relevant to understanding the way that social movements

9 Anders Burman, 'Chachawarmi: Silence and Rival Voices on Decolonisation and Gender Politics in Andean Bolivia', Journal of Latin American Studies, 43: I (201 I), pp. 65-9 I.

${ }^{10}$ Andrew Canessa, 'Sex and the Citizen: Barbies and Beauty Queens in the Age of Evo Morales', Journal of Latin American Cultural Studies, 17: I (2008), pp. 41-64; Andrew Canessa, Intimate Indigeneities. Race, Sex, and History in the Small Spaces of Andean Life (Durham, NC and London: Duke University Press, 2012).

${ }^{11}$ Deborah J. Yashar, Contesting Citizenship in Latin America: The Rise of Indigenous Movements and the Postliberal Challenge (Cambridge and New York: Cambridge University Press, 2005).

${ }^{12}$ José Antonio Lucero, Struggles of Voice: The Politics of Indigenous Representation in the Andes (Pittsburgh, PA: University of Pittsburgh Press, 2008).

${ }^{13}$ Jaquette, The Women's Movement in Latin America. 
are shaped. ${ }^{14}$ How did these factors affect indigenous movement trajectories and the role of women in indigenous organising? We find some discussion of indigenous women's hardship or success in electoral politics, particularly pertinent within indigenous parties and women's political participation in indigenous traditional political systems, but no broader effort to theorise the interconnections between national politics, gender politics within indigenous movement trajectories and indigenous women's mobilisation patterns. ${ }^{15}$

Still, as mentioned above, some studies have already shed light on many of the problems faced by indigenous women as they are marginalised or excluded from the politics of women's as well as indigenous rights. ${ }^{16}$ Most of these works emphasise the difficult position facing women as actors defending their communities and peoples against colonial, cultural and economic oppression, in a context where they are also faced with gender discrimination. The collective struggle of indigenous peoples tends to cast a shadow over the claims of women, whereas the latter face the same marginalisation in relation to non-indigenous women's struggles, usually based on an ethnocentric definition of gender. In addition, different authors have also investigated local processes of indigenous women's organising. ${ }^{17}$ What is missing and what we propose here is a framework that goes beyond a national or sub-national level and that studies indigenous women's mobilisation within the dynamics of the national indigenous movements and in relation to the national political process in a comparative perspective. Are there common factors that explain the emergence of indigenous women as political actors? Do they mobilise through similar types of organisations? What are the different organisational configurations that are found? How do indigenous women pressure for

${ }^{14}$ Verta Taylor, 'Gender and Social Movements: Gender Processes in Women's Self-Help Movements', Gender and Society, I3: I (1999), pp. 8-33; Yulia Zemlinskaya, 'Social Movements Through the Gender Lens', Sociology Compass, 4: 8 (2010), pp. 628-4I.

is Paloma Bonfil Sánchez, Dalia Barrera Bassols, Irma Aguirre Pérez, Los espacios conquistados: participación politica y liderazgo de las mujeres indigenas de México (México DF: PNUD México, 2008); Raúl L. Madrid, The Rise of Ethnic Politics in Latin America (Cambridge and New York: Cambridge University Press, 2012); Donna Lee Van Cott, Radical Democracy in the Andes (Cambridge and New York: Cambridge University Press, 2009).

${ }^{16}$ Hernández Castillo, 'The Emergence of Indigenous Feminism in Latin America'; Picq, 'Gender within Ethnicity: Human Rights and Identity Politics in Ecuador'; Manuela Lavinas Picq, 'Between the Dock and a Hard Place: Hazards and Opportunities of Legal Pluralism for Indigenous Women in Ecuador', Latin American Politics and Society, 54: 2 (2012), pp. I-33; Radcliffe, 'Indigenous Women, Rights and the Nation-State in the Andes'; Patricia Richards, 'The Politics of Gender, Human Rights, and Being Indigenous in Chile', Gender and Society, 19: 2 (2005), pp. 199-220.

${ }^{17}$ Gisela Espinosa Damián, Libni Iracema Dircio Chautla and Martha Sánchez Néstor, La coordinadora guerrerense de mujeres indigenas. Construyendo la equidad y la ciudadanía (México DF: UAM-X, CSH, 2010); Hernández (ed.), Etnografias e historias de resistencia; Speed, Hernández Castillo and Stephen, Dissident Women. 
change within indigenous movements? What kinds of roles do they manage to develop and who are their allies?

\section{Social Movements and Intersectionality}

We propose a comparative analysis of the organisational forms adopted by indigenous women in the creation of spaces where they can position themselves as autonomous political actors. Using the insights of intersectionality we study indigenous women's mobilisation in Peru, Bolivia and Mexico through identifying central processes that can explain the particular shape of their organising and discourses.

The integration of an intersectional approach to the political process model in social movement studies aims to account for the specific dynamics that shape social movement organisational forms. We build on the literature in social movement studies that suggest decentring the focus from state-movement relations to analyse how power structures affect movements' internal as well as external dynamics. ${ }^{18}$ Recent scholarship in social movement studies has laid the groundwork for incorporating intersectionality into our understandings of social movement dynamics. ${ }^{19}$ An intersectional perspective $^{20}$ views oppression as a result of the complex overlap of different

${ }^{18}$ Sonia E. Alvarez, Evelina Dagnino and Arturo Escobar (eds.), Cultures of Politics/Politics of Cultures: Re-visioning Latin American Social Movements (Boulder, CO: Westview Press, 1998); Elizabeth A. Armstrong and Mary Bernstein, 'Culture, Power, and Institutions: A Multi-Institutional Politics Approach to Social Movements', Sociological Theory, 26: I (2008), pp. 74-99; Margaret Levi and Gillian H. Murphy, 'Coalitions of Contention: The Case of the WTO Protests in Seattle', Political Studies, 54: 4 (2006), pp. 65 I-70; Nelson A. Pichardo, 'New Social Movements: A Critical Review', Annual Review of Sociology, 23 (1997), pp. 4I I-30; David Snow, 'Social Movements as Challenges to Authority: Resistance to an Emerging Conceptual Hegemony', Research in Social Movements, Conflicts and Change, 25 (2004), pp. 3-25; Suzanne Staggenborg and Verta Taylor, 'Whatever Happened to the Women's Movement?', Mobilization, IO: I (2005), pp. $37-52$.

19 Mary Bernstein, 'The Analytical Dimensions of Identity: A Political Framework', in Jo Reger, Daniel J. Myers and Rachel L. Einwohner (eds.), Identity Work in Social Movements (Minneapolis, MN: University of Minnesota Press, 2008), pp. 277-301; David Meyer, 'Social Movements. Creating Communities of Change', in Robin L. Teske and Mary Ann Tétreault (eds.), Feminist Approaches to Social Movements, Community, and Power (Columbia, SC: University of South Carolina Press, 2000), pp. 35-55; Jennifer C. Nash, 'Re-thinking Intersectionality', Feminist Review, 89 (2008), pp. I-I 5; Roth, Separate Roads to Feminism; Stéphanie Rousseau, 'Genre et ethnicité racialisée en Bolivie: pour une étude intersectionnelle des mouvements sociaux', Sociologie et sociétés, 4I: 2 (2009), pp. 135-60; Carolin Schurr, Performing Politics, Making Space: A Visual Ethnography of Political Change in Ecuador (Stuttgart: Franz Steiner Verlag, 2013); Erica Townsend-Bell, 'What is Relevance? Defining Intersectional Praxis in Uruguay', Political Research Quarterly, 64: I (201 I), pp. i 87-99.

${ }^{2}$ Patricia Hill Collins, Black Feminist Thought: Knowledge, Consciousness, and the Politics of Empowerment (New York: Routledge, I99I); Sirma Bilge, 'Recent Feminist Outlooks on Intersectionality', Diogenes, 71: I (2010), pp. 58-72. 
systems, which affects not only dynamics between the movement and other actors but also internal movement dynamics. The integration of an intersectional approach allows us to understand how the articulation of structures of power influence the formation of boundaries as well as the type of organisational structures that are created by social movements. This framework reflects our claim that group identities as built in social movements should be seen as a reflection of power relations within society as much as between society and the state.

\section{Boundaries and Negotiations of Difference}

Intersectionality informs our analysis in the way we focus on the emergence of a collective identity within indigenous movements that seek to represent the intersection of two systems of oppression, gender and ethnicity, which are also both strongly associated with class. To understand the emergence of indigenous women as social movement actors we argue that considering the mechanism of boundary making, the creation of an oppositional relationship between political actors, is essential. ${ }^{21}$ Generally, in social movement theory, boundary making is analysed in terms of a social movement challenging dominant groups that are conceived as external to the movement. However, boundary making also takes place within social movements. ${ }^{22}$ Many feminist movements have emerged out of the disillusion of women activists from New Left movements in the 1970 s. $^{23}$ When women decide to create autonomous spaces they create new boundaries that may be more or less oppositional in relation to a particular social movement, in our case, broader mixed-gender indigenous organisations or non-indigenous women's organisations.

Indigenous women's organisations generally subscribe to some sectors of the indigenous movement whose discourses are formulated in a largely ethnic frame based on opposition to the state and the national 'majorities' it purportedly represents. However, indigenous women also develop a discourse on gender, refusing to identify themselves exclusively with an ethnic identity. ${ }^{24}$ It is from this articulation of categories that women continually negotiate inclusion within the indigenous movement and, sometimes, that they formulate a distinct discourse and collective identity, thus becoming a specific political actor with a common base for organising together.

${ }^{21}$ Charles Tilly and Sydney Tarrow, Politique(s) du conflit: de la grève à la révolution (Paris: Presses de Science Po, 2008).

${ }^{22}$ Verta Taylor and Nancy Whittier, 'Collective Identity in Social Movement Communities', in Aldon D. Morris and Carol McClurg Mueller (eds.), Frontiers in Social Movement Theory (New Haven, CT: Yale University Press, I992).

${ }^{23}$ Suzanne Staggenborg, Gender, Family, and Social Movements (Thousand Oaks, CA: Pine Forge, 1998); Vargas, Feminismos en América Latina.

${ }^{24}$ Hernández Castillo, 'Entre el etnocentrismo feminista y el esencialismo étnico'. 
The challenge facing indigenous women in articulating and struggling for gender demands within the indigenous movement is reproduced in relation to the feminist/women's movement. In the same way that indigenous women might refuse to prioritise gender-blind indigenous demands over gendered demands within the indigenous movement, they also refuse to consider exclusively gender-based demands and criticise the ethnocentrism of the feminist/women's movement platforms. ${ }^{25}$ We can understand the creation of an indigenous women's movement as caused in some ways by both the failure of the indigenous movement to integrate a critical gender perspective within its demands and that of the feminist/women's movements to integrate a critique of racism as well as ethnic rights demands. ${ }^{26}$

Group identities can include, explicitly or not, different categories of social positionings. ${ }^{27}$ Social movements are made up of concrete groups acting together and shaping, in a fluid and contentious fashion, how they represent themselves in the public sphere. Collective identities tend to be constructed through essentialist frames as a strategy to simplify reality and amplify the legitimacy of grievances. ${ }^{28}$ This, we argue, is central for understanding how gender relations can be either idealised or simply absent from the discourse that frames a social movement's identity and platforms, as well as how other types of social relations between women can be erased by a movement's demands. Some social positionings are not represented in a social movement field while some group identities are essentialised, creating unified collective agencies at the cost of reproducing oppressive relations within and outside social movements. ${ }^{29}$ Such oppressive relations will consequently influence the organisational forms that are created by social movement actors, varying for example at the level of autonomy reached by different organisations or movements. ${ }^{30}$

\section{Internal Opportunities}

The emergence of indigenous movements throughout Latin America can be explained by the specific structural changes that took place during the 1980s

${ }_{25}$ Rosalva Aída Hernández Castillo and Andrew Canessa (eds.), Género, complementariedades y exclusiones en Mesoamérica y los Andes (Copenhagen: AbyaYala/IWGIA/Academia Británica de la Ciencia, 2012).

${ }^{26}$ Hernández Castillo, 'Entre el etnocentrismo feminista y el esencialismo étnico'.

27 Rousseau, 'Genre et ethnicité racialisée en Bolivie'.

${ }^{28}$ Joshua Gamson, 'Must Identity Movements Self-Destruct - A Queer Dilemma', Social Problems, 42 (1995), pp. 390-407; Stephen, 'Gender, Citizenship, and the Politics of Identity'.

${ }^{29}$ Rousseau, 'Genre et ethnicité racialisée en Bolivie'.

30 Anahi Morales Hudon, 'Struggling for Autonomy: The Dynamics of Indigenous Women's Movement in Mexico', unpubl. PhD diss., McGill University, Department of Sociology, 2014. 


\section{Stéphanie Rousseau and Anabi Morales Hudon}

and 1990 s. $^{31}$ However, these do not explain why some indigenous women started to deploy an autonomous discourse and create new organising spaces within the indigenous movement, nor does it illustrate the obstacles they faced. While changes in the state and, notably, changes in the laws and institutions that affect indigenous peoples and women, are central factors to consider, we propose paying close attention to political opportunities within internal movement dynamics by analysing the process of negotiation of women's demands and discourses about gender within the indigenous movement. This refers to internal challenges to core demands and discourse as well as to the reaction of movement organisations and leadership. To a certain extent this process is similar to the one characterising broader political opportunity structures as defined in the political process model. The political process model usually conceives political opportunities as external to social movements; the central factor that facilitates or constrains collective action, in this view, is a change in political opportunity structures. ${ }^{32}$ However, we propose going beyond a definition of opportunities focused on external dynamics to consider how the internal dynamics of social movements create, or fail to create, opportunities. We propose focusing on how internal challenges, opening/closing processes, which may or may not be prompted by external changes, are responded to from within the movement.

By opening/closing processes we mean a social movement's type of reaction to new claims and demands that emerge from within its ranks. This dynamic leads to an internal negotiation for recognition that can have different outcomes; the two opposite extremes are whether the movement substantially redefines its discourse in order to include new demands (opening), or whether it refuses to incorporate them (closing). The outcomes of these processes depend on the type of reaction and can be either an increase or decrease of the perceived need for boundary transgression by the challengers. As a consequence of such processes, in the cases under study, some women continue to mobilise within the indigenous movement's organisations, occupying important roles that enable them to integrate women's interests in the movement's agenda and discourse, while others create new spaces for mobilisation in order to put forward their demands independently of the mixed-gender organisations. As reported by different leaders and analysts, the resistance within indigenous movements to include indigenous women's specific claims constituted

${ }^{31}$ Rachel Sieder (ed.), Multiculturalism in Latin America: Indigenous Rights, Diversity, and Democracy (New York: Palgrave, 2002); Saúl Velasco Cruz, El movimiento indígena y la autonomía en México (México DF: Universidad Nacional Autónoma de México 2003); Yashar, Contesting Citizenship in Latin America.

${ }^{2}$ Tilly and Tarrow, Politique(s) du conflit. 
an important factor in their decision to create autonomous organising spaces and discourses. 33

In creating new spaces to organise and produce discourses, indigenous women navigate through the internal dynamics of the indigenous and feminist/women's movements. ${ }^{34}$ As such the production of new collective identities is associated with the emergence of new movement boundaries. This experience of negotiating indigenous women's specific demands through different collective identities and movements also received support from diverse actors that constitute important resources for indigenous women. Churches, feminist groups, and different national or international NGOs played an important role in supporting indigenous women's mobilisation and organisation around different issues. ${ }^{35}$ For instance, the progressive Catholic Church, through the creation of Base Ecclesial Communities, opened organisational spaces for women to participate in productive projects and discussion spaces. Women's groups and international NGOs also promoted this type of project, ranging from rural and indigenous women's consciousness-raising, to providing support and counselling to indigenous women's groups and the development of indigenous women's leadership.

The relationships between indigenous women's organisations and these other actors are complex and have been characterised by important collaborations, but also tensions emerging, for example, through the NGOisation phenomenon in Latin America that creates strong competition between groups. ${ }^{36}$ This has led in some cases to exclusionary practices that contribute to

33 Margarita Gutiérrez and Nelly Palomo, 'A Woman's View of Autonomy', in Aracely Burguete Cal y Mayor (ed.), Indigenous Autonomy in Mexico (Copenhagen: International Work Group for Indigenous Affairs, 2000), pp. 53-82; Tarcila Rivera, 'Mujeres indígenas americanas luchando por sus derechos', in Liliana Suárez Navaz and Rosalva Aída Hernández (eds.), Descolonizando el feminismo: teorias y prácticas desde los márgenes (Valencia: Universidad de Valencia, 2008), pp. 33I-48; Martha Sánchez Néstor, 'Construire notre autonomie: le mouvement des femmes indiennes au Mexique', Nouvelles Questions Féministes, 24: 2 (2005), pp. 50-64; Stephen, 'Gender, Citizenship, and the Politics of Identity'.

${ }^{34}$ Hernández Castillo, 'Entre el etnocentrismo feminista y el esencialismo étnico'.

35 Rosalva Aída Hernández Castillo, 'La voix des femmes dans le conflit du Chiapas: nouveaux espaces d'organisation et nouvelles revendications de genre', in Anna Maria Lammel and Jesus Ruvalcaba Mercado (eds.), Adaptation, violence et révolte au Mexique (Paris: L'Harmattan, 2002), pp. 33 I-48; Patricia Oliart, 'Indigenous Women's Organizations and the Political Discourses of Indigenous Rights and Gender Equity in Peru', Latin American and Caribbean Ethnic Studies, 3: 3 (2008), pp. 291-308; Radcliffe, Laurie and Andolina, 'The Transnationalization of Gender and Reimagining Andean Indigenous Development'; Stéphanie Rousseau, 'Indigenous and Feminist Movements at the Constituent Assembly in Bolivia: Locating the Representation of Indigenous Women', Latin American Research Review, 46: 2 (201 I), pp. 5-28.

${ }^{36}$ Sonia Alvarez, 'Advocating Feminism: The Latin American Feminist NGO "Boom", International Feminist Journal of Politics, I: 2 (1999), pp. I 8 I-209. 


\section{Stéphanie Rousseau and Anabi Morales Hudon}

reinforcing social boundaries between women. ${ }^{37}$ The power imbalance existing between middle-class mestiza and indigenous and popular women have more often been reinforced than questioned through the practices of NGO-based development projects. These tensions have been sufficiently important as to explain in part why indigenous women's organisations do not identify with the feminist/women's movement. ${ }^{38}$ Yet this does not mean that there is no collaborative work between the two, as our case studies also show.

\section{Autonomy and Organisational Type}

In her 1998 piece 'Analysing Women's Movements', Molyneux presented a typology of the forms adopted by women's collective action according to the type of authority structure under which they mobilised. ${ }^{99}$ She highlighted three types: independent organisations (women's self-governing collectives), associational linkages (institutional autonomy with political alliances), and directed mobilisations (authority and initiative comes from outside/above the collective). She insisted that 'there is no necessary relationship between forms of organisations and interest articulation', meaning that women's interests could be very well represented in directed mobilisations, for example. ${ }^{4 \circ}$ As will be clear in what follows, the study of indigenous women's recognition as political subjects shows contrasting paths towards autonomy and the representation of women's interests. Women's self-governing collectives are only one of the paths we found.

The social movement mechanism of boundary making as well as the internal opportunities within social movements are not the only ones at play in the emergence of indigenous women's movements and their specific trajectories. However, we argue that these are central for analysing the specificity of indigenous women's movements, particularly when approached from an intersectional perspective. We will now summarise the main features of the country cases we have studied before discussing the results of our comparative analysis.

\section{Our Cases}

Our comparative study involved three Latin American cases that contrast on a number of dimensions. Mexico, Peru and Bolivia represent a variety of

37 In this perspective Mohanty's pioneer work highlighted how power dynamics have affected feminist analyses and practices but also how this leads to specific forms of resistance. See Chandra Talpade Mohanty, Feminism Without Borders (Durham, NC and London: Duke University Press, 2003).

${ }^{8}$ Hernández (ed.), Etnografias e historias de resistencia.

39 Maxine Molyneux, 'Analysing Women's Movements', Development and Change, 29: 2 (1998), pp. 219-45.

40 Ibid., p. 230. 
temporal, national and regional dynamics in their patterns of indigenous mobilisation. The comparison sought to evaluate the impact of the relative strength of the indigenous movement in national politics on the opportunities for indigenous women to create spaces of their own within the movement. Field research was conducted in Peru in 2009, 2010 and 2012; in Bolivia in $20 \mathrm{I}$ and 2013; and in Mexico in $20 \mathrm{IO}$ and 20I I. On average, 30 semi-structured interviews were carried out in each country with indigenous women leaders of indigenous movement organisations, with their NGO allies, with local experts, with international cooperation agency staff, and with feminist activists.

While Mexico is marked by the federal nature of its political system, Peru is the most centralised polity of the three and Bolivia has a unitary political system but with strong regional centres and a new agenda of creating multilevel political autonomies. Even though statistical data on indigenous peoples is still often under-evaluating their numerical importance, and the criteria used for identification is restrictive in many cases (using language rather than self-identification), it is useful to cite the following as an overview. Mexico's indigenous population is a minority, and is estimated at about is million people ( 12.5 per cent of the total population), with 62 indigenous peoples, ${ }^{4 \mathrm{I}}$ most of them living in the south of the country. The absolute number of the indigenous population in Mexico is the largest in Latin America. The second largest is Peru with 6.5 million indigenous citizens, which makes up an important minority, approaching 25 per cent of the total population with 52 indigenous peoples..$^{42}$ Bolivia's indigenous population is a majority ( 5 million) and is estimated at 62 per cent of the total population, with 36 indigenous peoples. ${ }^{43}$

Mexico's indigenous movement is probably the most well known because of the important breakthrough of the Zapatista (EZLN) armed uprising in the mid-I990s. ${ }^{44}$ However, since the early 2000 s the Zapatistas have retreated to the local level in order to strengthen their project of autonomy. After the signing of the San Andrés Accords on Indigenous Rights and Culture in I 996, where apparently the Zapatistas had managed to obtain autonomy

${ }^{41}$ See webpage of the Comisión nacional para el desarrollo de los Pueblos indígenas, available at www.cdi.gob.mx/index.php?option $=$ com_content\&view $=$ article\&id $=1387 \&$ Itemid $=24$ (last accessed I6 March 2014).

42 See webpage of the Ministry of Culture: http://bdpi.cultura.gob.pe/presentacion (last accessed 16 March 2014).

43 See //www.ilo.int/indigenous/Activitiesbyregion/LatinAmerica/Bolivia/lang--es/index.htm (last accessed I6 March 2014).

${ }^{44}$ For detailed accounts of the Mexican indigenous movement, see among others George Allen Collier and Elizabeth Lowery Quaratiello, Basta!: Land and the Zapatista Rebellion in Chiapas (Oakland, CA: The Institute for Food and Development Policy, 1994); Lynn Stephen, ¡Zapata lives! Histories and Cultural Politics in Southern Mexico (Berkeley, CA: University of California Press, 2002). 
and collective rights, the Mexican government took several steps backwards and conflict re-emerged in Chiapas. The adoption of the Law on Indigenous Rights and Culture in 200I, a diluted version of the San Andrés Accords, negatively impacted the national indigenous movement as this represented a closure of opportunities. Beyond the Zapatista movement, other regional indigenous movements have made great inroads at the level of community self-governance. In Oaxaca the indigenous movement has mobilised and strengthened its organisations since the 1980 os. In Guerrero, indigenous organisations have been mainly present at the local level, particularly after the decline of state-level organisations in the 2000s. These historically strong indigenous regional movements have nonetheless not managed to sustain a process leading to national unity, such as the one initiated with the creation of the National Indigenous Congress (CNI) in 1996, which was supported by the Zapatista National Liberation Army (EZLN) and local indigenous organisations. Moreover, the national organisations and networks that emerged in the r 990 s and strengthened indigenous organisations at the local level have disintegrated and contributed to a retreat to the local level and a decline of the capacity to mobilise at the national level.45 Indeed, the majority of their political gains remain at the local and regional (state) levels.

Peru's and Bolivia's indigenous movements are also divided geographically, but this time largely between the Highlands and Amazon/lowland regions. Strong regional organisations have consolidated except in the Peruvian Highlands. The Bolivian case demonstrates greater 'success' of indigenous movement influence on the state, with the election of Evo Morales as President in 2005 and the adoption of a radically new constitution in 2009 that provides numerous rights and reforms demanded by the indigenous movements. ${ }^{46}$ These gains were obtained through the joint collaboration of all major regional indigenous organisations that managed to form a 'Pact of Unity' during the Constituent Assembly. However, once the new constitution was adopted, a number of issues led to tensions between the various organisations, eventually leading to the dissolution of the pact. The division falls largely along the line of the organisations that have formed the governing MAS party, mostly peasant federations (Confederación Sindical Única de Trabajadores Campesinos de Bolivia, CSUTCB and Confederación Sindical de Comunidades Interculturales de Bolivia, CSCIB), confronting other sectors of the indigenous movement, such as the movement for the reconstruction of ancestral ayllus in

${ }^{45}$ Rodolfo Stavenhagen, 'Struggle and Resistance: The Nation's Indians in Transition', in Andrew Selee and Jacqueline Peschard (eds.), Mexico's Democratic Challenges: Politics, Government, and Society (Stanford, CA: Stanford University Press, 2010), pp. 25 I-67.

${ }^{46}$ For detailed accounts of the Bolivian indigenous movement, see among others Xavier Albó, Pueblos indios en la politica (La Paz: Plural Editores and CIPCA, 2002); Nancy Grey Postero, Now We Are Citizens: Indigenous Politics in Postmulticultural Bolivia (Stanford, CA: Stanford University Press, 2007). 
the Highlands (Consejo Nacional de Ayllus y Markas del Qullasuyu, CONAMAQ), and the lowland indigenous organisations united in the Confederation of Indigenous Peoples of Bolivia (CIDOB). The division is therefore not organised strictly along ethnic or geographical lines, but rather, according to the different trajectories in constructing what indigenous peoples' rights and autonomy means. To simplify, the pro-government sector is based on union-type organisations and peasant/migrant economies based on individual parcelling of the land. It conceives autonomy mainly in relation to popular control of the state apparatus, something that the MAS purportedly embodies. The opposition is made up of a greater variety of organisations that share the ideal of territorial-based, collective autonomy for indigenous peoples' organisations and emphasise in a much more pronounced fashion the need to protect the environment as a central issue in indigenous cultural identities.

Peru has long been considered an exceptional case of deviation from the Latin American pattern of indigenous mobilisation, as the Peruvian indigenous movement is poorly articulated at the national level and in the Highlands, where a majority of the indigenous population lives. ${ }^{47}$ However, recent developments around the issue of the right to prior consultation on major projects affecting indigenous communities have galvanised indigenous mobilisation and fostered more collaboration between Highland and Amazon based organisations. A Peruvian indigenous Pact of Unity was created in November 20 I I, which was a major step forward for the movement following the Peruvian Congress's adoption of the first law in Latin America specifically designed to implement the right to prior consultation contained in ILO Convention 169. The Law on the Right to Prior Consultation of Indigenous and Native Peoples was adopted in September $20 \mathrm{II}$ in the first months of the Ollanta Humala government, in reaction to national shock following the dramatic end of the protests led by Amazonian indigenous organisations affiliated with the pan-Amazonian Asociación Inter-étnica de Defensa de la Selva Peruana (AIDESEP). The protests ended in 2009 with violent clashes between indigenous protesters and security forces that caused the deaths of 34 people.

However, since its adoption, the government has shown no decisive sign of wanting to apply the law in a straightforward manner. Additionally, the Pact

47 For detailed accounts of the Peruvian indigenous movement, see among others María Elena García and José Antonio Lucero, 'Authenticating Indians and Movements: Interrogating Indigenous Authenticity, Social Movements and Field Work in Peru', in Laura Gotkowitz (ed.), Histories of Race and Racism. The Andes and Mesoamerica from Colonial Times to the Present (Durham, NC: Duke University Press, 201 I), pp. 278-98; Maritza Paredes, 'En una arena hostil. La politización de lo indígena en el Perú', in Carlos Meléndez and Alberto Vergara (eds.), La iniciación de la politica. El Perú político en perspectiva comparada (Lima: Fondo editorial PUCP, 2010), pp. 213-44. 
of Unity has been severely weakened by problems in the main indigenous organisation of the Highlands, the Confederation of Communities Affected by Mining (CONACAMI), which faces a leadership crisis that has paralysed it since late 20I2. Moreover, in early 20I4, AIDESEP left the Pact of Unity, again leaving Peru's indigenous movement highly fragmented, and with no clear national agenda apart from the implementation of the right to prior consultation and the creation of a state machinery to address indigenous peoples' rights.

\section{Indigenous Women's Recognition as Political Subjects}

Our approach to indigenous women's recognition as political subjects implies that they occupy specific organisational spaces and that they become political agents in the national public sphere acting collectively in their name and with a sufficient level of strength to be acknowledged by the media. This process dates back to the 1980 s in Bolivia, to the early 2000 s in Peru, and the 1990 s in Mexico. When we consider the breakthrough of indigenous movements into national political dynamics, we notice that indigenous women have appeared as political subjects early in the structuring of indigenous organising processes. Yet they began to become more autonomous political subjects in the indigenous movements in the late I 990 os in the case of Mexico, in the early 2000 s in Bolivia and the late 2000 s in Peru. Globally speaking, therefore, we can associate indigenous women's empowerment as social movement actors with the broad normative changes that have occurred in Latin America in relation to gender equality. The 1990 s is a crucial decade for the integration of gender equality as a norm guiding state policy and the priorities of many international cooperation agencies and national NGOs. This is an important context that has benefited indigenous women as well, as we will explain below when referring to the role of external actors.

In the Andean countries, the indigenous movement grew in strength in the 2000s. In Bolivia in particular, the empowerment of the indigenous movement with the election of Evo Morales has unleashed a dynamic of emulation/competition between indigenous organisations that has benefited women's representation and participation. In the case of Mexico, the organisational spaces and actions of the indigenous movement in the 1990s, inspired by the central space occupied by women in the EZLN, created favourable opportunities for indigenous women to voice specific demands and organise autonomously.

One of the key comparative findings of our study is that indigenous women emerged as social movement actors through a variety of organisational forms that in part determine the degree of autonomy they can exercise as political subjects. Basically four broad types of organisational patterns have developed 
and are more or less widespread: a specific women's space in a mixed-gender organisation; a women-only organisation created out of a mixed-gender organisation and that remains related to the latter; an organisation based on gender dualism in all positions of authority (married couples occupy all the positions jointly within the organisation); and a women-only organisation with no permanent link to any other organisation (independent organisations).

In Peru, we found a dual pattern. On the one hand, the most important organisations in the Highlands and the Amazon (AIDESEP, CONACAMI, and the peasant union confederations $\mathrm{CNA}$ and $\mathrm{CCP}$ ) have created a specific space within their organisation to channel and promote women's participation. ${ }^{48}$ Women's Secretariats have usually offered some space for women leaders to gain experience and sometimes move to other leadership positions within the organisation, such as the vice-presidency or even the presidency of the organisation. While these spaces have also been promoted at the level of regional affiliates, the growing number of women participating in mixedgender indigenous organisations has not translated into an agenda that would specifically address indigenous women's needs. On the other hand, the case of Peru is also characterised by the formation of independent indigenous women's organisations acting autonomously. Two such national organisations have been created in the 2000s. The Organización Nacional de Mujeres Indígenas Andinas y Amazónicas del Peru (ONAMIAP) was created in 2009 out of a decade-long process of training and networking among grassroots rural women's organisations promoted by a Lima-based NGO dedicated to indigenous cultural revival. Chirapaq Centro de Culturas Indígenas del Perú, led by Tarcila Rivera Zea. ONAMIAP was the instigator of the indigenous movement's Pact of Unity and had a central role in its coordination. This initiative was described by ONAMIAP's leader, Gladys Vila, as the best strategy for gaining some recognition from mixed-gender organisations. The other independent organisation, the Federación de Mujeres Campesinas, Artesanas, Indígenas, Nativas y Asalariadas del Peru (FEMUCARINAP) was created in 2006 through the decision by a few leaders of the CCP, one of the two national peasant union confederations, to break out of this male-dominated organisation and form an independent women's voice. It adopted a platform

${ }^{48}$ AIDESEP created its Women's Programme in 2002; prior to that, in 1996 its statutes were modified to make one out of five positions on the Executive council be filled by a woman; in 2000 , this number was raised to two. The creation of these spaces was the direct product of insider pressure from women, combined with the pressure coming from one of AIDESEP's main funders. CONACAMI created its Women's Secretariat in 2006, one of the 12 positions on its Executive Council; it was later changed to a Gender and Youth Secretariat. The Women's Secretariat was created mainly due to funders' demands, and because of the greater space occupied by women in other indigenous organisations. The two peasant unions CCP and CNA have had peasant women's federations as affiliates in some departments for several decades, but no specific mechanisms at the national leadership level. 
uniting indigenous and rural women as well as urban migrant workers, and participated in Peru's indigenous movement's Pact of Unity.

Both ONAMIAP and FEMUCARINAP gathered women from all of the different regions of the country, thus achieving what no other indigenous organisation could achieve: presenting themselves as a national voice that represented indigenous women all over the country, thus breaking down the geographic distinction between Highland and Amazonian indigenous peoples. While both certainly have much work left to do to fulfil their promise of broad representativeness, they each nonetheless brought together around 20 department-level organisations. One of their main weaknesses was the fact that they remained two national organisations rather than a single one and that their two presidents had a highly competitive relationship.

In Bolivia, the dominant pattern is that of women-only organisations created out of a mixed-gender organisation and that remains related to the latter. The most important indigenous women's organisation, the Confederación nacional de mujeres campesinas indígenas originarias de Bolivia 'Bartolina Sisa' (CNMCIOB 'BS'), was created in 1980 out of the CSUTCB, itself the largest peasant union in the country. Its creation was the result of negotiations between women, who were putting internal pressure on the movement, and male leaders who were willing to enhance the organisation's mobilising capacity by capitalising on women's availability and strength.

The CNMCIOB 'BS' (called the Bartolinas) led the way in inspiring other indigenous women to convince or assert themselves over the male leaders of their organisations in order to create their own organisation. ${ }^{49}$ By becoming a central organisation of the Bolivian indigenous movement in the 2000 , the Bartolinas projected a very successful model while at the same time its hegemonic pretensions to represent all indigenous women unleashed a reaction among diverse sectors of the indigenous movement. As mentioned at the outset of this article, the Confederación nacional de mujeres indígenas de Bolivia (CNAMIB) was created in 2008 out of the Confederación de Pueblos Indígenas de Bolivia (CIDOB), the main indigenous confederation of the lowlands of Bolivia. It was initially not supported by the male leadership of CIDOB, but according to CNAMIB's leaders and other observers, the need to counter the Bartolinas' attempt to represent all Bolivian indigenous women eventually allowed the CNAMIB to create a positive and collaborative relationship with CIDOB.

Another case of gender parallelism is the Confederación Sindical de Mujeres de Comunidades Interculturales de Bolivia (CSMCIB), created in $20 \mathrm{ro}$ out of the Confederación Sindical de Comunidades Interculturales de Bolivia

49 This organisational 'gender parallelism' dates back even further if we consider the experience of the Miners' Housewives Associations (Comités de Amas de Casa), who were crucial in the popular struggle against authoritarianism in the 1970 . 
(CSCIB), the organisation of migrant populations from the Quechua and Aymara Highlands, who have been migrating to the lowlands since the late I950s. The organisation was previously named 'Confederación sindical de colonizadores', from its creation in I97 I until the election of Evo Morales in 2005, when it decided to change the term 'colonizadores' to 'intercultural communities'. The CSMCIB was created in order to better represent and coordinate women from the 'intercultural communities' and as a way to maintain some equilibrium between the CSCIB and the CSUTCB/Bartolinas. The two organisations are indeed the most important bases of the MAS governing party, and up to 2010 the first did not have its women's branch.

Besides this predominant pattern of organising, which we termed 'gender parallelism', Bolivia also has the only case of an organisation based on gender dualism in all positions of authority. The Consejo Nacional de Ayllus y Markas del Qullasuyu (CONAMAQ) was founded in 1997 by Aymara and Quechua communities who sought to rebuild the ancient ayllus, markas and suyus that existed on their territory (pre-colonial indigenous territories with customary economic and political institutions). The organisation was designed from the beginning with a structure of leadership that assigned married couples to fill each position jointly. According to the gender ideology promoted by CONAMAQ, the Mama T'alla (female authority) and the Tata (male authority) are conceived as complementary, just as the heterosexual married couple is conceived as the basic social unit of the community. The leadership model chosen by CONAMAQ caused the organisation some problems in institutional contexts where seats are conceded individually for one representative of each organisation.

The dual pattern found in Peru is also predominant in Mexico, where we find women's organising spaces within mixed-gender indigenous and peasant organisations in the 1990 s predominantly, while during the late I 990 and 2000 s we see the creation of autonomous organisations by indigenous women coming from previously existing mixed-gender organisations. Similarly to the Confederación Campesina del Peru, women within the peasant and indigenous national organisations in Mexico created Women's Commissions or Women's Areas in the late 1980 and $19905 .{ }^{50}$ Such commissions or areas aimed to promote peasant and indigenous women's projects as well as their participation in the organisation. ${ }^{51}$ This inclusion was sometimes a response to funding agencies that promoted women-focused projects, or a strategy to increase organisational membership. In other words, the organisations' main concern was not to integrate women as autonomous subjects with particular interests, but rather to integrate them in the pursuit of the

so Sarah A. Radcliffe and Sallie Westwood, 'Viva': Women and Popular Protest in Latin America (London; New York: Routledge, 1993).

${ }^{51}$ Christine Eber and Christine Kovic (eds.), Women of Chiapas (New York: Routledge, 2003). 
organisation's broader goals. ${ }^{52}$ This was the case notably with the creation in I 989 of the Women's Area within the National Union of Regional Peasant Organisations (UNORCA), in order to promote local and regional women's participation in different projects. Indigenous women also created a women's commission within one of the most important indigenous organisations at the national level in the 1990s, the Pluralistic Indigenous National Assembly for Autonomy (ANIPA). However, in this case, the creation of the Women's Commission in 1995 was the result of the rejection of women's specific demands within the ANIPA. A similar situation occurred within the National Indigenous Congress (CNI) and the Guerrero Council for 500 Years of Indian, Black and People's Resistance.

When women in the CNI tried to incorporate their perspectives into different spaces, the resistance they faced became sufficiently difficult as to make it necessary for them to organise autonomously. Following the same goal as women from ANIPA, women from the CNI combined their efforts to organise the first national meeting of indigenous women in 1997 in the city of Oaxaca, where more than 600 women participated, representing approximately 26 different indigenous groups. The Coordinadora Nacional de Mujeres Indígenas (CONAMI) was created during this meeting, becoming the first structure at the national level to gather local organisations of indigenous women and actively promote indigenous women's participation and leadership. ${ }^{3}$ Thus CONAMI became the primary space for formulating and representing indigenous women's demands and interests at the national level.54 It was instrumental in providing a space for coordinating indigenous women at the national level but more importantly, it organised numerous workshops for training indigenous women to develop tools to promote their rights and to train other women from their communities and groups.

If training took a central place in the first years of CONAMI, from the beginning CONAMI also endeavoured to bring together local groups of indigenous women to collaborate and organise in regional processes. Although top-down initiatives for creating regional coordination were deployed, the outcomes depended on the local dynamics of women's organising in those regions. CONAMI succeeded in providing resources to local groups to

$\$ 2$ Karina Ochoa Muñoz, 'Sembrando desafíos. Experiencias organizativas de mujeres indígenas en Guerrero', in Gisela Espinosa Damián, Libni Iracema Dircio Chautla and Martha Sánchez Néstor (eds.), La coordinadora guerrerense de mujeres indígenas. Construyendo la equidad y la ciudadanía (México DF: Universidad Autónoma Metropolitana (UAM), Unidad Xochimilco Coordinadora Guerrerense de Mujeres Indígenas (CGMI), 2010), pp. 13 I -64 .

53 Gutiérrez and Palomo, 'A Woman's View of Autonomy'.

54 Maylei Blackwell, 'Engendering the "Right to have Rights": The Indigenous Women's Movement in Mexico and the Practice of Autonomy', in Natividad Guitérrez Chong (ed.), Women, Ethnicity and Nationalisms in Latin America (Aldershot: Ashgate, 2007), pp. $193-222$. 
organise and build alliances between women from different states. In terms of creating structures at the sub-national level however, the impact was rather limited to a few states, primarily in the southeast (Guerrero, Oaxaca and Chiapas).

\section{The Dynamics of Indigenous Women's Emergence as Social Movement Actors}

As explained above and drawing on social movement theory and intersectionality, we identified several mechanisms that help to explain the dynamics of indigenous women's organising processes. They manifested themselves somewhat differently in each context, both nationally and in relation to different indigenous organisations. However, the comparison has allowed us to draw several conclusions.

First, the more powerful an indigenous movement or organisation is in relation to its access to the state and political representation, the more indigenous women tend to remain within the same organisational 'family' where they were trained as leaders and activists. For example, when they create their own parallel but related organisation, women benefit from the extensive prestige and resources of the male-dominated organisation, yet can develop their own voice and position themselves relatively autonomously in the public sphere. The Bolivian case exemplifies this trend the most. In this scenario, the opening of the movement to women expressing their demands as political subjects is strategically transferred 'outside' the male-dominated organisation, yet presented as the best way to recognise in due form the specific contribution made by women to the movement. This also avoids the construction of boundaries as indigenous women act jointly with indigenous male-dominated organisations, yet they can also create their own space to pursue 'complementary' issues of greater interest to them.

In contrast in Peru, where the indigenous movement is the weakest, women have either gained more space within mixed-gender organisations but with little result in terms of political empowerment as a social group, or created their own independent organisations. The latter road has been the more worthwhile in terms of political positioning, as the two independent women's organisations have managed to develop their own agendas and gain recognition by state institutions and through their participation in some coordinating spaces among indigenous movement organisations. The formation of independent organisations is associated with a perceived closing of the indigenous movement to women's voices, which provoked the creation of a gender boundary within the movement. Yet this boundary is rather flexible in practice, as in many instances all major organisations acted in concert. This being said, some indigenous women have also managed to rise to the highest leadership positions within mixed-gender 
organisations, a phenomenon that was unimaginable a decade ago and that indicates some change in the mentality of these organisations' leaders.

The case of Mexico presents a more complex situation regarding the relationship between the strength of its indigenous movement and women's organising processes. The strength of the indigenous movement in the $1990 \mathrm{~s}$ represented a major opportunity for indigenous women in terms of participation, the creation of networks, access to resources, and allies' support. This allowed women to participate fully within mixed-gender organisations but also to develop their own discourses and organisational structures. When the indigenous movement declined in the early 2000 s women had constructed the networks that would allow them, while retreating to the regional level, to create new and autonomous organisations from which they mobilised as autonomous political actors. 55 These organisations are principally the Indigenous Women's Assembly of Oaxaca (AMIO), the Coordination of Indigenous Women of Guerrero (CGMI) and the Indigenous Women's Coordination of Chiapas (COEMI).

The rise of indigenous women's organising spaces can also be interpreted as the construction of a new boundary in relation to the women's/feminist movements. Indeed, as women organising outside of the established channels of representation for women in civil society, their emergence as political subjects presents a challenge to the category 'women' as a homogeneous category, as occurred in the United States, for example, with the emergence of Black and Chicana feminisms. ${ }^{56}$ The majority of the organisations we studied explicitly distanced themselves from feminist movements, even if they acknowledged the importance of the work done by feminists in advancing women's rights in their country as well as the support of some feminist organisations for their own organising processes. They pointed to historical social structures that positioned indigenous women in subordinate positions in relation to urban middle-class women who were the instigators and leaders of the feminist movements. As mentioned by a Quechua leader in Bolivia describing the relationship between feminist activists and indigenous women activists: 'They are from the city and think that everything is easy. For us, in the countryside, it's more difficult. They know how to read, some are professionals. We are not professionals. We have ideas, we know how to think, but very often they pretend to know more than us'.57

These hierarchies were also invoked when indigenous women claimed to carry different understandings of oppression and emancipation. ${ }^{8}$ In general, indigenous women emphasise the collective nature of oppressive relations as

5s Morales Hudon, Struggling for Autonomy.

${ }^{56}$ Roth, Separate Roads to Feminism.

57 Interview, I5 March 201 I, Bolivia.

${ }^{58}$ This resonates with the classic work of Chandra Talpade Mohanty. 
being historically located in colonial and racist structures. Ethnic and gender oppression are inter-related in their experiences and affect how they articulate their political platforms. Emancipatory struggles are conceived as the joint efforts of men and women, who make complementary contributions to their communities' wellbeing and therefore should both act together in representing these communities. As a result, the indigenous women we interviewed positioned themselves clearly in the terrain of the indigenous movement rather than the feminist or even the women's movement, with the exception of one independent indigenous women's organisation in Peru (FEMUCARINAP), whose identity was less univocally indigenous, and who maintained an alliance with some feminist organisations. Moreover, in the case of Mexico, some of the indigenous women leaders clearly identify themselves as feminists, but see their feminism as grounded in indigenous women's movements.

However, in practice, we have observed the strategic use of feminist resources by indigenous women in cross-boundary dialogues and collaboration. In the case of Bolivia, permanent mechanisms for inter-organisational collaboration to advance joint platforms on women's rights have been created between middle-class urban feminists and indigenous women, beginning with the election of the Evo Morales government. ${ }^{59}$ These mechanisms have been key for the recent adoption of a series of laws on gender parity and alternation for all electoral processes, on political harassment against elected women, and on violence against women, among other issues. In the case of Peru, FEMUCARINAP's alliance with some key feminist organisations was based on mutual respect for each other's platform and priorities, and selective support where interests coincide. Additionally, in certain instances, feminists and indigenous women leaders have built connections on an individual basis. For example, when Teresita Antazu, an important leader of AIDESEP, was persecuted by the state in 2009 , a feminist lawyer assumed her defence. In Mexico, different organisations have been instrumental for indigenous women's organising processes. Their support was manifested through projects, workshops, training, and also financing. Among these organizations we find Kinal Antzetik, an organisation that was actively involved in the process of creating CONAMI and that supported local and state-level organising processes in Chiapas and Guerrero, or COMLATEZIN, a feminist organisation supporting peasant and indigenous women's groups in Oaxaca. ${ }^{60}$

Another conclusion that can be derived from the comparison is that the role of external actors in pushing for the opening of specific spaces for women inside indigenous organisations is again stronger in the case of the weakest indigenous movement, in Peru. International NGOs like Oxfam and Ibis

59 Rousseau, 'Indigenous and Feminist Movements at the Constituent Assembly in Bolivia'.

${ }^{60}$ Paloma Bonfil Sánchez, 'Mujeres indígenas y derechos en el marco de las sociedades multiétnicas y pluriculturales de América Latina', Ra Ximhai, 8: I, 201 2, pp. I4 I-67. 
Denmark (among others) and the German international cooperation agency GTZ (among others), have used the financial and political support they give to the main mixed-gender indigenous movement organisations as leverage to convince the predominantly male leadership to innovate and create institutionalised mechanisms for women's participation and representation. The independent indigenous women's organisations were created as a result of more autonomous processes, yet also relied heavily on financial resources provided by NGOs or international cooperation agencies. In Bolivia, the same NGOs (Ibis and Oxfam) were also instrumental in assisting women from the CONAMAQ in developing training tools and opportunities to organise meetings with the lowland indigenous women's organisation CNAMIB. Yet the emergence of Bolivian indigenous women as political subjects is more attributable to women's own agency and to their retaining close links to male-dominated mass organisations than to specific pressures by external actors. The case of Mexico is similar to the path followed in Bolivia, yet the relationship established between indigenous women and feminist organisations was key to mobilising resources and support for indigenous women's organising processes. However, the type of relationship that exists between indigenous women and external actors varies greatly from one region to another. In Oaxaca, for example, the relationship with external actors is less mediated and more collaborative than in Chiapas, where the collaboration between mestizas and indigenous women did not systematically lead to the creation of independent organisational structures for indigenous women. ${ }^{61}$

Another important dimension of the dynamics we studied is the way indigenous women articulate ethnicity and gender in their discourses, and how that contributes to shaping movement identity. Indeed, besides empowering women and creating specific organisational spaces for them within the indigenous movement, women's articulation of ethnicity and gender has fundamentally shifted the movement's identity. One key result common to all our cases is that indigenous movements now recognise the need to address violence against women. This move represents a substantial victory as it required male leaders to admit that such problems exist in indigenous communities, and that they need to be addressed. Yet clearly, this issue remains the priority of women, and without their continual pressure it is likely that indigenous organisations would not hold it as a political issue worth pursuing.

In the case of the weaker indigenous movement (Peru), the mixed-gender indigenous organisations are slow in granting the importance they should to this issue (violence against women), as it rarely if ever appears in their statements or documents. Conversely, Peru's two independent women's organisations make it a central demand. In Bolivia, reports on dramatic cases and

${ }^{61}$ Morales Hudon, Struggling for Autonomy. 
statistics on violence against women led to the adoption of a law against feminicide in 2013 by the MAS government, but again it is quite clear that the political work on this issue is predominantly done by indigenous women's organisations together with other women's organisations. ${ }^{62}$ In Mexico the work on this issue is also conducted primarily through the collaboration of indigenous women and feminist organisations, through spaces such as the Sexual and Reproductive Rights Network (DDSER) and the Indigenous Women's House projects (CAMI).

We also noted in our comparison that indigenous women's articulation of ethnicity and gender tends to be associated with the defence of food sovereignty, along with claims to protect and value indigenous traditional medicine. Indigenous women identify predominantly with the role of care-givers in a broad sense, from the family to the community, and to the natural environment, which is considered as home and family symbolically. This frame has been integrated into the identity of indigenous movements in general, reinforcing the traditional frame of the indigenous as the defender of the planet against the ills of modern techno-industrial capitalism. Yet far from leaving women in a role of care-giver strictly speaking, an interesting facet of indigenous women's interpretation of these themes is also that of their role as producers, either as agricultural producers or as craftswomen.

Overall, the greatest transformation in indigenous movements' identity is towards a more gender-balanced leadership structure, as demonstrated by the specific organisational configurations that we highlighted above. As could be suspected, a particularity of indigenous women's political discourse is its insistence on women's representation as a social group within indigenous organisations. In Bolivia, this goes further and includes state institutions at all levels, whereas in Mexico, indigenous women's political discourse promotes their participation in different political spaces: traditional indigenous self-governments at the local level and political parties. As shown in our discussion about organisational configurations, there are some regional and national variations, yet overall the past decade has seen quite dramatic changes in the gender identity of indigenous movements. In the case of Bolivia, the strong rise of indigenous women as political actors has also translated into the adoption of the principle of gender parity and alternation in all elected positions within formal state institutions, including those at the highest judicial level, as guaranteed by the 2009 Constitution and a series of electoral laws adopted in 2010.

However, this greater gender balance in indigenous movements is also influenced by the trajectory that led to particular organisational configurations. In Peru, for example, the independent indigenous women's organisations were

${ }^{62}$ Law No 348 'Ley Integral para Garantizar a las Mujeres una Vida Libre de Violencia', 9 March 2013. 
seen as a clear threat by male-dominated organisations and thus suffered constant exclusion and campaigns to delegitimise them. As told by one Quechua leader, "men were saying "now that women have formed their organisations we will form male-only organisations!" and they insisted that we women did not have territories, that only indigenous peoples had territories'. ${ }^{63}$ This exclusion only gradually faded away when indigenous women's organisations found ways to work to strengthen the role of the indigenous movement in national politics, as occurred when the ONAMIAP launched and structured the work of the Pact of Unity between the different national indigenous organisations, and when FEMUCARINAP was elected as representative of Peru in the transnational alliance Via Campesina. Only when contributing to the 'greater cause' as defined by indigenous male leaders were they accepted as part of the indigenous movement.

\section{Conclusion}

The social positioning of indigenous women within indigenous movements reflects complex power relations that are visible in the emergence of new collective identities but also in internal organisational structures and dynamics. This confirms that adopting an intersectional approach in the study of social movements is a useful framework for analysing how power structures affect both internal and external movement dynamics. Our comparison shows that the organising paths followed by indigenous women vary depending on internal dynamics within indigenous movements and the relationships established with external actors. These paths reflect distinct experiences of oppression, but more importantly, different opportunities within the indigenous movement to bring about changes in their internal dynamics. The internal opportunities or constraints indigenous women face within indigenous organisations, along with the perceived necessity for boundary transgression, the role of external actors and the resources they made available to women, have been shaped by such power relations.

Indigenous women's independent organisations have primarily formed in the context of weak (Peru) or weakening (Mexico) indigenous movements in national politics. We interpret this as reflecting that greater organisational autonomy was more attractive or necessary for indigenous women when the mixed-gender organisations were not producing satisfactory results. In contrast, in Bolivia the emergence of indigenous women's organisations paralleling and related to mixed-gender indigenous organisations has expanded at a similar pace to the strengthening of the indigenous movement in national politics. These contrasting paths towards developing organisations should not, ${ }^{63}$ Interview, I2 December 2012, Peru. 
however, be taken by themselves as indicators of a greater or lesser degree of success of indigenous women in achieving recognition as political subjects and in pursuing autonomous agendas. The fact that most indigenous women leaders have first mobilised within mixed-gender organisations sets the frame for understanding autonomy as relationally constructed in the context of the broader dynamics of indigenous movements. Indeed, indigenous women have built spaces of their own that both maintain their affiliation with indigenous organisations while winning the right to speak as political subjects. While this article has not discussed the meaning of autonomy for the different indigenous women we interviewed, as we emphasised throughout the article, this recognition as political subjects and the empowerment it provides is contingent on women's capacity to find ways to mobilise in their own name within or in relation to mixed-gender indigenous organisations. The opportunities to do so without creating an oppositional boundary within the movement are important in light of indigenous women's discourse on gender and ethnicity and in light of the legitimacy they need to build in order to create their own spaces.

One key factor that affects the dynamics of indigenous women's mobilisation is the relationships between indigenous women and external organisations that have contributed to fostering boundary making between women and even between indigenous women and men. Indigenous women identified their experience of exclusion or subordination, even if sometimes through collaborative links, as a key reason to build their own organising spaces and articulate their own public voices. These relationships have also been instrumental in providing resources for strengthening indigenous women's organising processes. In most cases, however, these processes have enriched indigenous movements rather than fragment them along gender lines. Even in the case of independent organisations, women's contribution to indigenous movements is noticeable in how they join forces with mixed-gender organisations in various coordinating spaces and fora. Indigenous women's recognition as political subjects has positively led to more balance in male-female leadership and participation within indigenous movements, which have broadened their platforms to include at least some of women's priorities.

This being said, it is important to underline that due to space limitations, this article has not discussed the daily difficulties faced by indigenous women in their efforts to be recognised as full members of indigenous organisations with equal rights to voice and vote. Nor have we reported on the violent repression that they endure together with their male comrades, as part of indigenous movements' interactions with the state and private corporations. Many indigenous women activists told us that one of their frustrations and impetus for building new organising spaces was related to how they experienced violent protests and their aftermath. Many claimed that their male 
comrades sent them to the front of the marches where they would encounter police or military agents. This strategic decision was justified by the argument that the latter would be less inclined to use drastic repressive tactics when facing women. While indigenous women portrayed themselves as proudly and effectively assuming this role, they also resented the lack of reward in return for their courage: no seat at the press conference, no official leadership position. This, among other issues, eventually pushed many of them to seek more autonomous organising spaces. These and other stories will be analysed elsewhere.

\section{Spanish and Portuguese abstracts}

Spanish abstract. Basado en una investigación comparativa este artículo analiza las trayectorias organizativas de las mujeres indígenas y la creación de espacios donde se posicionan como actoras políticas autónomas. A partir de teorías sobre movimientos sociales e interseccionalidad, presentamos una tipología de las formas organizativas adoptadas por mujeres indígenas en Perú, Bolivia y México en las dos últimas décadas. Una de las principales conclusiones de nuestro estudio comparativo es que las mujeres indígenas se vuelven actoras de movimientos sociales a través de diferentes formas organizativas que en parte determinan el grado de autonomía que pueden ejercer como sujetas políticas.

Spanish keywords: mujeres indígenas, México, Perú, Bolivia, movimientos indígenas

Portuguese abstract. Baseado em pesquisa comparativa, este artigo analisa a trajetória organizativa de mulheres indígenas e a criação de espaços onde as mulheres apresentam-se como sujeitos políticos autônomos. A partir da teoria dos movimentos sociais e da interseccionalidade, apresentamos uma tipologia de formas organizacionais adotadas por mulheres indígenas no Peru, na Bolívia e no México ao longo das últimas duas décadas. Uma das principais conclusões de nosso estudo comparativo aponta que mulheres indígenas tornaram-se atores de movimentos sociais através de diferentes formas organizacionais que determinam em parte o nível de autonomia que elas podem exercer como sujeitos políticos.

Portuguese keywords: mulheres indígenas, México, Peru, Bolívia, movimentos indígenas 